\title{
Building an Inclusive Workforce Through Ownership in Crises
}

\author{
Franziska M. Renz \\ San José State University
}

This study develops a process of how organizations can build an inclusive workforce by addressing fundamental challenges of the society, which were made even more apparent by the COVID-19 pandemic. Societal challenges are examined through the lens of psychological ownership theory. This theory is also used to derive organizational practices to confront the societal challenges through managerial support for employee ownership. Job and work design, communication, training and development, and compensation and benefit practices can be implemented to create leadership opportunities for minorities and women, and inclusive and equitable workplace conditions beyond a crisis. Eventually, the entire organization can benefit.

Keywords: psychological ownership, diversity, equity, inclusion, leadership, crisis management

\section{INTRODUCTION}

The COVID-19 pandemic has undoubtedly brought to light the fundamental challenges that shape organizations and society in general. Some employees were hit harder by the COVID-19 pandemic than others based on their industry, race/ethnicity, and gender. While essential workers faced increased exposure to the virus and extraordinary stress, minorities and female employees are generally overrepresented in precarious jobs that lack living wages and basic benefits (Rattner \& Franck, 2021). These and other challenges reduce the psychological ownership that employees take in their jobs and workplaces (Pierce, Dirks, \& Kostova, 2001, 2003).

However, employee ownership is strongly needed by organizations to overcome a crisis (Brown, 1989). Organizations can provide managerial support for employee ownership through certain organizational practices that address industry-, race/ethnicity-, and gender-specific challenges. These practices offer employees opportunities to take control in the organization, learn about the workplace, and invest their selves so that the psychological ownership of employees eventually increases and benefits not just the employees, but the entire organization beyond the crisis (Pierce et al., 2001, 2003; Renz \& Posthuma, 2021). Empirically supported outcomes of employee ownership include increased job performance, increased job satisfaction, and reduced turnover intentions (Bernhard \& O'Driscoll, 2011; Dawkins, Tian, Newman, \& Martin, 2017; Wang, Law, Zhang, Li, \& Liang, 2019).

Figure 1 illustrates the process of how fundamental challenges of the society can be addressed. In the following, employee ownership is explained as a major mechanism driving the process, as well as the challenges that shape society and practices that organizations can implement to build an inclusive workforce. A conclusion is offered at the end. 


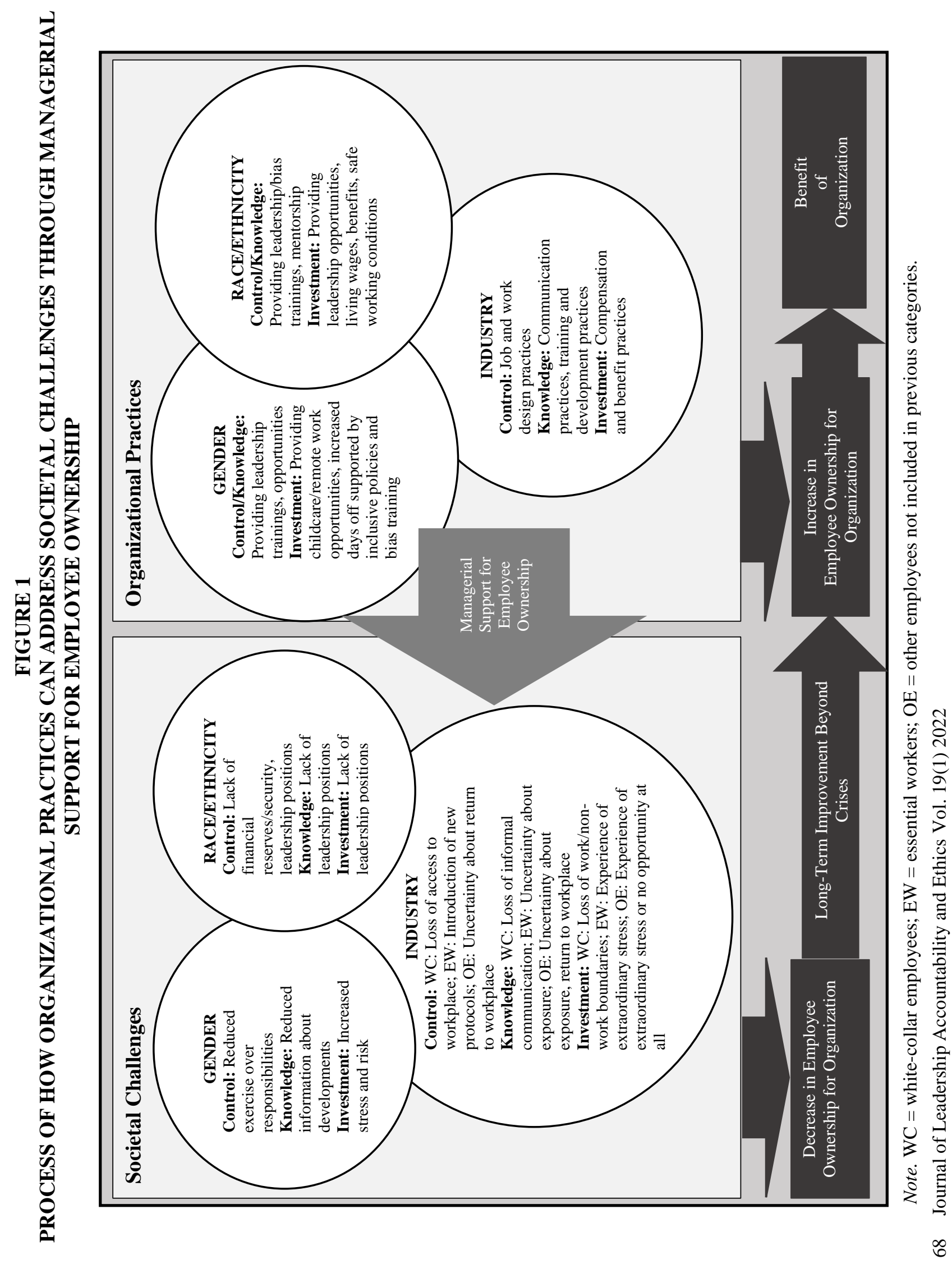




\section{EMPLOYEE OWNERSHIP}

The psychological ownership that employees can develop in the workplace is a key for organizations to manage societal challenges. In times of no crisis, the workplace provides employees with various ways to experience control (Pierce et al., 2001, 2003; Pierce \& Jussila, 2011). Employees can, for example, autonomously determine when and how they perform their jobs. They can decide how to organize their workspaces, how to collaborate with team members, how to lead subordinates, and how to advise customers. Similarly, the workplace provides employees with various ways to acquire knowledge (Pierce et al., 2001, 2003; Pierce \& Jussila, 2011). Knowledge can be gained, for example, by learning about the organization's mission and vision as well as stakeholders and financial data. Employees can also increase their knowledge about the organization by collaborating with managers, coworkers, and subordinates on projects. Much information may be shared through informal channels, for instance at the water cooler or the coffee maker. The workplace additionally provides employees with various ways to invest their selves (Pierce et al., 2001, 2003; Pierce \& Jussila, 2011). Employees invest their selves through their resources. They can invest, for example, their time, energy, and creativity in the development of a product, the retention of a customer, or the identification of synergies among team members.

By investing their resources, the results of the employees' efforts (e.g., products, customer relationships, team collaboration) become representations of the employees' selves (Marx, 1976). Employees integrate the fruits of their labor and creations into their extended selves (Belk, 1988, 2000; Dittmar, 1992; Pierce et al., 2001, 2003). Likewise, knowledge and control in the workplace allow employees to integrate the organization and their jobs into their extended selves (Belk, 1988, 2000; Dittmar, 1992; McClelland, 1951). Since individuals perceive an urge to keep up their extended selves, employees want to protect their control over the decisions which they are allowed to make in the workplace, and the continuous flow of information that increases their knowledge about the workplace (James, 1981). Different types of information allow employees to form deep relationships with the organization and their jobs (Beaglehole, 1932). The effects of employees' control, knowledge, and investment on psychological ownership allow to address important societal challenges.

\section{SOCIETAL CHALLENGES}

The COVID-19 pandemic made crucial challenges of our society even more evident. These societal challenges relate to working conditions in certain industries as well as discrimination due to the membership in racial/ethnic or gender groups.

\section{Industry}

Certain industries, such as restaurants and bars, travel and transportation, entertainment, personal services, retail, and manufacturing, were more affected by the measures implemented to limit the spread of COVID-19 than others (e.g., white-collar industries; Vavra, 2020). Hence, the control that employees of different industries experienced in the workplace was affected differently by the pandemic. Due to the pandemic, many employees lost a part of their control of the workplace. Many white-collar employees lost the access and right to use their physical workplaces, and were asked to perform their tasks remotely (Vasel, 2021). In contrast, essential workers had to adapt to new workplace protocols, such as social distancing and enhanced cleaning protocols (Occupational Safety and Health Administration, 2021). They gave up a part of their control by changing the ways they were used to perform their jobs and learning new techniques. Other employees, who were not considered essential but could not work remotely either (e.g., restaurant servers, travel agents), lost control by not knowing when they could return to perform their jobs (Vavra, 2020).

Furthermore, employees lost a part of their knowledge about the workplace due to the pandemic. For example, when white-collar workers were asked to work remotely, they lost informal interactions with their coworkers around water coolers, coffee makers, and photocopiers (Fayard \& Weeks, 2007). Although information was still distributed through formal (e.g., virtual meetings, emails) and some informal channels 
(e.g., WhatsApp; McFarland \& Ployhart, 2015), the intimacy and closeness of in-person interactions could not be recreated (Wang, Liu, Qian, \& Parker, 2020). Thus, the information distributed through informal channels was limited. Although essential workers could access their workplaces, they were also confronted with a loss of information. At the beginning of the pandemic, they did not know how they could effectively protect themselves against COVID-19 because only limited research was available (He, Yi, \& Zhu, 2020). Later on, research indicated that $17 \%$ of infected persons were asymptomatic and did not show any signs of being sick (Byambasuren, Cardona, Bell, Clark, McLaws, \& Glasziou, 2020). Thus, essential workers such as nurses and grocery store workers might be in contact with multiple infected persons on a daily basis without any possibility to know about others' infection and their own exposure. Employees of non-essential businesses who could not work remotely faced the same uncertainty once they were able to return to their workplaces. They additionally lacked information about possible future business closures and re-openings due to the pandemic (Karin et al., 2020).

In addition, the pandemic led to employees losing a part of their investment in the workplace. In the case of white-collar employees, remote work reduced employees' opportunities and resources to invest their selves. The boundaries of employees' work and personal lives were blurred. Many employees had to take care of their children at home and support them with their school assignments during the workday (Vasel, 2021). Thus, employees might be interrupted and distracted from their job responsibilities. They might not perceive to have the resources, such as time, energy, and creativity, available to invest their selves into the workplace. Research found that employees suffered from high stress due to working remotely (e.g., Hayes, Priestley, Ishmakhametov, \& Ray, 2020). Likewise, essential workers experienced extraordinary stress because of their continuous contact with the public. This stress might lead to PTSD, and alcohol and substance abuse problems (McKay \& Asmundson, 2020; Tan et al., 2020). Non-remote employees of nonessential businesses might be confronted with similar experiences when they returned to the workplace. As long as they could not return, they lacked the opportunity to invest their selves (Pierce et al., 2001, 2003).

\section{Race/Ethnicity}

These industry-specific challenges were reinforced by an employee's race/ethnicity. Members of minority groups generally have fewer financial reserves and thus face issues paying for basic needs (e.g., healthcare, housing, nutrition) in case of unexpected unemployment (Couch, Fairlie, \& Xu, 2020). Thus, minorities had less control to make a conscious decision to continue or not continue working during the pandemic. In fact, many essential workers perform precarious work which lacks employment security, workplace protections, and living wages (e.g., grocery store workers; Benach, Vives, Tarafa, Delclos, \& Muntaner, 2016; Kantamneni, 2020). Especially Hispanic employees are disadvantaged in this context because they constitute a disproportionate large number of grocery store workers (Kantamneni, 2020).

Moreover, minorities' underrepresentation in leadership positions increases their lack of control in the workplace (Cook \& Glass, 2014; Cunningham, 2020; Kilian, Hukai, \& McCarty, 2005). Not being in a managerial role hinders employees' participation in decision-making and contribution to the entire organization. Consequently, members of racial/ethnic minorities encounter decreased opportunities to learn and enhance their knowledge about the organization. The lack of leadership positions additionally limits minorities' possibilities to take on responsibility and invest their selves into the organization, for example through their efforts, time, and creativity (Pierce et al., 2001, 2003). Especially Asian American employees were likely to be affected by such workplace discrimination due to the pandemic because China was believed to be the epicenter of COVID-19 (Kantamneni, 2020).

\section{Gender}

The impact of the described circumstances could be even more profound when gender is considered as an additional factor. Women in general and women of color in particular faced multiple role conflicts due to the pandemic. Since schools and daycares were closed to limit the spread of the disease, women, who traditionally take on more household and caretaking responsibilities, needed to identify ways to perform their jobs while educating and caring for their children at home (Kantamneni, 2020). Women working remotely experienced more stress and thus could invest less of their resources into their jobs. Consequently, 
they could gain less information about developments in the organization and exercise less control over their responsibilities (Restubog, Ocampo, \& Wang, 2020). Women working essential jobs were confronted with another tough situation: how to work full-time without childcare (Kantamneni, 2020)? This conflict came also with employees' decreased ability to invest their selves into the workplace as well as reduced control and knowledge about the job (Restubog et al., 2020). The additional risk of contracting COVID-19 and infecting persons they care for might lead to women exiting the workforce (Rattner \& Franck, 2021).

\section{ORGANIZATIONAL PRACTICES}

Organizations can contribute to overcoming the discussed societal challenges by providing managerial support for employee ownership.

\section{Industry}

Industry-specific challenges can be mitigated by increasing employees' control through job and work design practices (Posthuma, Campion, Masimova, \& Campion, 2013). Employees can be included in decision-making (Chi \& Han, 2008; O’Driscoll, Pierce, \& Coghlan, 2006) and policy formulation (Hideg, Michela, \& Ferris, 2011), for example of remote work policies (e.g., Do all employees have to be available via phone or online during a certain time of day? What happens if a bad internet connection prevents a team member from participating in a meeting? Is the appearance of children and pets accepted during team meetings? Are files distributed through shared folders or email?) and new workplace protocols, such as social distancing and enhanced cleaning protocols (e.g., How are the guidelines from national institutions such as the Center for Disease Control and Prevention implemented? Which cleaning and hygiene procedures are implemented to keep everyone safe? Who does return to the workplace on which dates? Which procedures do employees have to follow when they think they might be infected?). Consequently, organizations enhance job complexity by giving employees broader tasks (Brown, Pierce, \& Crossley, 2014), and facilitate supervision since some burden is removed from middle managers or department heads.

Furthermore, increasing employees' knowledge can alleviate industry-specific challenges through communication practices (Posthuma et al., 2013). Organizations can share business information, such as strategic plans or merger and acquisition plans, and financial information, such as profits, with their employees (Chi \& Han, 2008). Especially in times of a crisis, employees may seek such information to reduce uncertainty about how the future of the organization and their jobs might look like: How is the organization doing financially? Does management plan to lay off employees? Do the company's customers pay the bills? Are the company's suppliers able to provide inputs or are there any shortages? Can the company survive the crisis? Ample information should be provided through formal channels since informal channels may be impeded.

Additionally, organizations can implement training and development practices (Posthuma et al., 2013) to inform employees about the current status of the crisis and strategies to deal with and overcome the crisis. Organizations can train employees about how COVID-19 is transmitted, and how employees can protect themselves and their coworkers. Cisco's Chief People, Policy and Purpose Officer Fran Katsoudas, for example, explained, "We recognized that our employees were coming to us for guidance for everything: the pandemic, how they lived, wanting to know what was safe and what wasn't safe [...] It became very natural for us to have meetings where we had medical and mental health practitioners and discussions about business strategy, all in the same meeting." (Vasel, 2021, para. 21).

Increasing employees' investment can additionally address industry-specific challenges through compensation and benefit practices (Posthuma et al., 2013). Organizations can share resources such as profits. Profit sharing plans allow employees to be rewarded if they contribute to the financial success of the organization (Chi \& Han, 2008; Han \& Kim, 2018; Liu, 2012). Organizations can also support employees by providing funds to establish remote workspaces. For example, in May 2020, Google gave each of their employees an allowance of $\$ 1,000$ to purchase supplies that they needed to work from home. Other companies provided monthly stipends to cover expenses for office supplies and equipment such as noise-cancelling headphones, screens and chairs, and high-speed internet, as well as counseling, childcare, 
and increased days off (Liu, 2020; Vasel, 2021). Coveo, an artificial intelligence company, spent "seven figures overnight" (Vasel, 2021, para. 18).

Similarly, organizations can provide resources that ensure the health and safety of employees who return to the traditional workplace, such as masks, face shields, hand sanitizers, and wipes. Organizations can also install plexiglass partitions and air filters that prevent the circulation of viruses and bacteria. Such resources may reduce employees' anxiety and financial concerns, and allow employees to use their own resources (e.g., time, energy, creativity) to focus on their jobs. At the same time, organizations can signal employees that they are perceived as valuable and important to the organization (Van Dyne \& Pierce, 2004).

\section{Race/Ethnicity}

Race/ethnicity-specific challenges can be mitigated by giving employees, especially employees of historically underrepresented minorities, more control and knowledge in the workplace. Organizations can support minority employees in obtaining leadership positions by creating leadership trainings and mentorship programs. Such initiatives have been applied in various areas such as education, health care, and business. Analyses of these contexts have shown that mentorship can improve mentees' self-efficacy, self-confidence, empowerment, performance, and networking scope (Brown-DeVeaux, Jean-Louis, Glassman, \& Kunisch, 2021; De Janasz, Ensher, \& Heun, 2008; Haring, 1999). In addition, all employees can be trained about implicit and explicit biases, especially racial/ethnic biases. In the context of the COVID-19 pandemic, a training about the origins of the virus might mitigate the discrimination and attacks that many Asian Americans faced inside and outside of the workplace. Many businesses operated by Asian Americans were vandalized and threatened because of racist claims (Jan, 2021). Asian Americans were also attacked on the streets, such as a San José, CA resident who was followed home by a stranger who punched him in the face (Samson, 2021).

Moreover, increasing the leadership responsibility of minorities can enhance their possibilities to invest themselves in the workplace through their jobs. Organizations can also foster employee investment and overcome race/ethnicity-specific challenges by paying employees a fair wage that allows them to cover basic needs. Since minorities are overrepresented in precarious jobs (Benach et al., 2016; Kantamneni, 2020), a fair wage allows them to build financial reserves and make a conscious decision to work during a crisis such as the COVID-19 pandemic. Organizations can similarly participate in efforts to raise the minimum wage on state and federal levels (U.S. Department of Labor Wage and Hour Division, n.d.). Additional benefits, such as health care and frequent testing in the context of the COVID-19 pandemic, could drastically improve the circumstances of minorities and lower the COVID-19 mortality rate which was higher among minorities than among White Americans (Essien \& Venkataramani, 2021). Besides, safe working conditions, such as providing PPE and frequent cleaning protocols, could prevent work-related injuries from occurring in precarious jobs performed by minorities (Occupational Safety and Health Administration, n.d.).

\section{Gender}

Gender-specific challenges can be alleviated by providing female employees with opportunities and training to obtain leadership positions, and thus control and knowledge in the workplace. Verizon, for example, started an initiative to offer resources such as training, mentorship, and networking opportunities, to women-owned businesses and women entrepreneurs suffering from the COVID-19 pandemic. The purpose was to prevent women from exiting the workforce due to burnout and increased household and caretaking responsibilities, and "to create a future of work that works for all women" (Verizon, 2021, para. $3)$.

Similarly, female employees' investment can be enhanced by providing childcare opportunities or financial support for such services, opportunities for remote work beyond the COVID-19 pandemic, and increased days off. Coveo, Microsoft, Reddit, and Yelp planned to increase employees' flexibility regarding where employees performed their jobs (Vasel, 2021). However, organizations need to ensure that no stigma is attached to such opportunities and resources. Managers and coworkers may perceive female employees using these opportunities and resources as less productive and career focused. Coworkers not using these 
opportunities may have more face time with managers and better access to information, assignments, and positive relationships with the manager (Vasel, 2021). Thus, organizations need to develop inclusive and equitable workplace policies, and train managers and employees to prevent implicit and explicit biases.

\section{CONCLUSION}

Organizations are in the position to confront fundamental societal challenges across industries by supporting employee ownership. Organizations can build an inclusive workforce and provide opportunities for control, knowledge, and investment to employees regardless of race/ethnicity and gender beyond the COVID-19 pandemic. Other crises, such as wildfires, hurricanes, and floods, also put employees, especially minorities and women, in precarious circumstances. The challenges that employees face (e.g., lack of leadership responsibilities, lack of support for non-work duties, or lack of financial security) increase their vulnerability and decrease their ownership in the workplace. If organizations implement practices that provide managerial support for employee ownership, societal challenges can be tackled for a long-term improvement beyond the crisis while the organization benefits.

\section{REFERENCES}

Beaglehole, E. (1932). Property: A study in social psychology. New York, NY: The Macmillan Company. Belk, R.W. (1988). Possessions and the extended self. Journal of Consumer Research, 15(2), 139-168. doi: $10.1086 / 209154$

Belk, R.W. (2000). Are we what we have? In A. Benson (Ed.), I shop therefore I am: Compulsive spending and the search for self (pp. 76-104). Northvale, NJ: Jason Aronson Press.

Benach, J., Vives, A., Tarafa, G., Delclos, C., \& Muntaner, C. (2016). What should we know about precarious employment and health in 2025? Framing the agenda for the next decade of research. International Journal of Epidemiology, 45, 232-238. doi: 10.1093/ije/dyv342

Bernhard, F., \& O'Driscoll, M.P. (2011). Psychological ownership in small family-owned businesses: Leadership style and nonfamily-employees' work attitudes and behaviors. Group \& Organization Management, 36(3), 345-384. doi: 10.1177/1059601111402684

Brown, G., Pierce, J.L., \& Crossley, C. (2014). Toward an understanding of the development of ownership feelings. Journal of Organizational Behavior, 35(3), 318-338. doi: 10.1002/job.1869

Brown, T.L. (1989). What will it take to win? Industry Week, 15.

Brown-DeVeaux, D., Jean-Louis, K., Glassman, K., \& Kunisch, J. (2021). Using a mentorship approach to address the underrepresentation of ethnic minorities in senior nursing leadership. JONA: The Journal of Nursing Administration, 51(3), 149-155. doi: 10.1097/NNA.0000000000000986

Byambasuren, O., Cardona, M., Bell, K., Clark, J., McLaws, M.L., \& Glasziou, P. (2020). Estimating the extent of asymptomatic COVID-19 and its potential for community transmission: Systematic review and meta-analysis. Official Journal of the Association of Medical Microbiology and Infectious Disease Canada, 5(4), 223-234. doi: 10.3138/jammi-2020-0030

Chi, N.W., \& Han, T.S. (2008). Exploring the linkages between formal ownership and psychological ownership for the organization: The mediating role of organizational justice. Journal of Occupational and Organizational Psychology, 81(4), 691-711. doi: 10.1348/096317907X262314

Cook, A., \& Glass, C. (2014). Above the glass ceiling: When are women and racial/ethnic minorities promoted to CEO? Strategic Management Journal, 35(7), 1080-1089. doi: 10.1002/smj.2161

Couch, K.A., Fairlie, R.W., \& Xu, H. (2020). Early evidence of the impacts of COVID-19 on minority unemployment. Journal of Public Economics, 192, 104287. doi: 10.1016/j.jpubeco.2020.104287

Cunningham, G.B. (2020). The under-representation of racial minorities in coaching and leadership positions in the United States. In S. Bradbury, J. Lusted, \& J. van Sterkenburg (Eds.), 'Race', ethnicity and racism in sports coaching (pp. 3-21). London, United Kingdom, and New York, NY: Routledge. 
Dawkins, S., Tian, A.W., Newman, A., \& Martin, A. (2017). Psychological ownership: A review and research agenda. Journal of Organizational Behavior, 38, 163-183. doi: 10.1002/job.2057

De Janasz, S.C., Ensher, E.A., \& Heun, C. (2008). Virtual relationships and real benefits: Using ementoring to connect business students with practicing managers. Mentoring \& Tutoring: Partnership in Learning, 16(4), 394-411. doi: 10.1080/13611260802433775

Dittmar, H. (1992). The social psychology of material possessions: To have is to be. New York, NY: St. Martin's Press.

Essien, U.R., \& Venkataramani, A. (2021). Data and policy solutions to address racial and ethnic disparities in the COVID-19 pandemic. JAMA Network. Retrieved from https://jamanetwork.com/channels/health-forum/fullarticle/2765498

Fayard, A.L., \& Weeks, J. (2007). Photocopiers and water-coolers: The affordances of informal interaction. Organization Studies, 28(5), 605-634. doi: 10.1177/0170840606068310

Han, K., \& Kim, A. (2018). Differential impact of short-term and long-term group incentives. Employee Relations, 40(3), 549-564. doi: 10.1108/ER-10-2016-0202

Haring, M.J. (1999). The case for a conceptual base for minority mentoring programs. Peabody Journal of Education, 74(2), 5-14. doi: 10.1207/s15327930pje7402_2

Hayes, S., Priestley, J.L., Ishmakhametov, N., \& Ray, H.E. (2020). 'I'm not working from home, I'm living at work": Perceived stress and work-related burnout before and during COVID-19. Retrieved from https://psyarxiv.com/vnkwa/download?format=pdf

He, W., Yi, G.Y., \& Zhu, Y. (2020). Estimation of the basic reproduction number, average incubation time, asymptomatic infection rate, and case fatality rate for COVID-19: Meta-analysis and sensitivity analysis. Journal of Medical Virology, 92(11), 2543-2550. doi: 10.1002/jmv.26041

Hideg, I., Michela, J.L., \& Ferris, D.L. (2011). Overcoming negative reactions of nonbeneficiaries to employment equity: The effect of participation in policy formulation. Journal of Applied Psychology, 96(2), 363-376. doi: 10.1037/a0020969

James, W. (1981). The principles of psychology. Cambridge, MA and London, United Kingdom: Harvard University Press.

Jan, T. (2021, March 25). Asian American businesses are defending themselves against rise in anti-Asian violence. The Washington Post. Retrieved from https://www.washingtonpost.com/business/2021/03/25/asian-owned-businesses-hate-crimes/

Kantamneni, N. (2020). The impact of the COVID-19 pandemic on marginalized populations in the United States: A research agenda. Journal of Vocational Behavior, 119, 103439. doi:10.1016/j.jvb.2020.103439

Karin, O., Bar-On, Y.M., Milo, T., Katzir, I., Mayo, A., Korem, Y., . . \& \& Alon, U. (2020). Adaptive cyclic exit strategies from lockdown to suppress COVID-19 and allow economic activity. MedRxiv. doi: 10.1101/2020.04.04.20053579

Kilian, C.M., Hukai, D., \& McCarty, C.E. (2005). Building diversity in the pipeline to corporate leadership. Journal of Management Development, 24(2), 155-168 doi:10.1108/02621710510579518

Liu, J. (2020, August 25). How companies are preparing employees for long-term work-from-home. CNBC. Retrieved from https://www.cnbc.com/2020/08/25/how-companies-are-supporting-workfrom-home-until-2021or-forever.html

Liu, M.S. (2012). Impact of knowledge incentive mechanisms on individual knowledge creation behavior - An empirical study for Taiwanese R\&D professionals. International Journal of Information Management, 32(5), 442-450. doi: 10.1016/j.ijinfomgt.2012.02.002

Marx, K. (1976). The Marx-Engels reader (2nd ed., Edited by R. C. Tucker.). New York, NY: Norton. McClelland, D. (1951). Personality. New York, NY: Holt, Rinehart \& Winston.

McFarland, L.A., \& Ployhart, R.E. (2015). Social media: A contextual framework to guide research and practice. Journal of Applied Psychology, 100(6), 1653-1677. doi: 10.1037/a0039244 
McKay, D., \& Asmundson, G.J. (2020). Substance use and abuse associated with the behavioral immune system during COVID-19: The special case of healthcare workers and essential workers. Addictive Behaviors. doi: 10.1016/j.addbeh.2020.106522

O’Driscoll, M.P., Pierce, J.L., \& Coghlan, A.M. (2006). The psychology of ownership: Work environment structure, organizational commitment, and citizenship behaviors. Group \& Organization Management, 31(3), 388-416. doi: 10.1177/1059601104273066

Occupational Safety and Health Administration. (2021, January 29). Protecting workers: Guidance on mitigating and preventing the spread of COVID-19 in the workplace. United States Department of Labor. Retrieved from https://www.osha.gov/coronavirus/safework

Occupational Safety and Health Administration. (n.d.). Coronavirus disease (COVID-19). United States Department of Labor. Retrieved from https://www.osha.gov/coronavirus

Pierce, J.L., \& Jussila, I. (2011). Psychological ownership and the organizational context. Cheltenham, United Kingdom: Edward Elgar Publishing, Inc.

Pierce, J.L., Kostova, T., \& Dirks, K.T. (2001). Toward a theory of psychological ownership in organizations. Academy of Management Review, 26(2), 298-310. doi:10.5465/AMR.2001.4378028

Pierce, J.L., Kostova, T., \& Dirks, K.T. (2003). The state of psychological ownership: Integrating and extending a century of research. Review of General Psychology, 7(1), 84-107. doi: 10.1037/10892680.7.1.84

Posthuma, R.A., Campion, M.C., Masimova, M., \& Campion, M.A. (2013). A high performance work practices taxonomy: Integrating the literature and directing future research. Journal of Management, 39(5), 1184-1220. doi: 10.1177/0149206313478184

Rattner, N., \& Franck, T. (2021, March 5). Black and Hispanic women aren't sharing the job market recovery. CNBC. Retrieved from https://www.cnbc.com/2021/03/05/black-and-hispanic-womenarent-sharing-in-the-job-market-recovery.html

Renz, F.M., \& Posthuma, R.A. (2021). Employees can feel like owners: Perk up attitudes, performance, and teamwork. Organizational Dynamics, 50(2), 100788. doi: 10.1016/j.orgdyn.2020.100788

Restubog, S.L.D., Ocampo, A.C.G., \& Wang, L. (2020). Taking control amidst the chaos: Emotion regulation during the COVID-19 pandemic. Journal of Vocational Behavior, 119, 103440. doi:10.1016/j.jvb.2020.103440

Samson, C. (2021, March 11). Asian man punched in the face by stranger who followed him home in San Jose. Yahoo! Life. Retrieved from https://www.yahoo.com/lifestyle/asian-man-punched-facestranger-161127059.html

Tan, B.Y., Chew, N.W., Lee, G.K., Jing, M., Goh, Y., Yeo, L.L., . . \& Sharma, V.K. (2020). Psychological impact of the COVID-19 pandemic on health care workers in Singapore. Annals of Internal Medicine, 173(4), 317-320. doi: 10.7326/M20-1083

U.S. Department of Labor Wage and Hour Division. (n.d.). Minimum wage. United States Department of Labor. Retrieved from https://www.dol.gov/agencies/whd/minimum-wage

Van Dyne, L., \& Pierce, J.L. (2004). Psychological ownership and feelings of possession: Three field studies predicting employee attitudes and organizational citizenship behavior. Journal of Organizational Behavior, 25(4), 439-459. doi: 10.1002/job.249

Vasel, K. (2021, March 11). The pandemic forced a massive remote-work experiment. Now comes the hard part. CNN Business. Retrieved from https://www.cnn.com/2021/03/09/success/remotework-covid-pandemic-one-year-later/index.html

Vavra, J. (2020, March 27). Shutdown sectors represent large share of all US employment. Becker Frieman Institute for Economics at the University of Chicago. Retrieved from https://bfi.uchicago.edu/insight/blog/key-economic-facts-about-covid-19/\#shutdown-sectors

Verizon. (2021, March 5). Verizon opens doors to champion women and confront ongoing crisis [Press release]. Retrieved from https://www.verizon.com/about/news/verizon-opens-doors-championwomen-and-confront-ongoing-crisis 
Wang, B., Liu, Y., Qian, J., \& Parker, S.K. (2020). Achieving effective remote working during the COVID-19 pandemic: A work design perspective. Applied Psychology: An International Review, 70(1), 16-59. doi: 10.1111/apps.12290

Wang, L., Law, K.S., Zhang, M.J., Li, Y.N., \& Liang, Y. (2019). It's mine! Psychological ownership of one's job explains positive and negative workplace outcomes of job engagement. Journal of Applied Psychology, 104(2), 229-264. doi: 10.1037/apl0000337

76 Journal of Leadership Accountability and Ethics Vol. 19(1) 2022 